JELTL (Journal of English Language Teaching and Linguistics)

e-ISSN: 2502-6062, p-ISSN: 2503-1848

2017, Vol. 2 (3)

www.jeltl.org

doi: http://dx.doi.org/10.21462/jeltl.v2i3.64

\title{
A Profile of the Grammatical Variation in British and American English
}

\author{
Md. Faruquzzaman Akan \\ Faculty of English, King Khalid University, KSA \\ E-mail:f.akan@yahoo.com
}

\begin{abstract}
This research paper attempts to focus on the main and major differences and idiosyncrasies of grammar and grammar related issues in British and American English. These differences have a great influence on learning and using the English language. In fact, British and American English are one language having two (slightly) different grammars. Although there is a popular notion about American English to be more simplified and flexible, we have to keep it in mind about the subtleties, complexities and identifications too. American English is now different from its British mother and we could say it is more than another dialect due to its importance as well as control over the world affairs at present. The fall of the then USSR, the US popular media, open market, globalization, the internet etc have made American English more powerful than ever before. But still today, the number of British English users is more than that of American English. Sometimes, it is noticed by and large that the misuse and the misconception in handling these two major varieties of English pose various problems. So, the main concern of this current paper is to remove the possible mistakes and confusions about the two different but related varieties of English, specially in most of the areas of grammar, syntax and the like.
\end{abstract}

Keywords: AmE, BrE, grammar, syntax, lingua franca, foreign language 


\section{INTRODUCTION}

Language, the arbitrary means of human communication or interaction, uses structured words for its written form and vocal sounds for the spoken form. Language has so many varieties or types which are not possible for an individual to learn and use accurately. But all of us should at least know the English language well for its being the most common lingua franca - the global language - essentially the international language. In recent times, the necessity of learning English has become more important than any time in the past. English is now most widely taught as a foreign language in more than 100 countries including China, Russia, Germany, Spain, Egypt, Brazil etc. Although English has huge variants, British and American are the two major ones. It is stated that English is obviously a single language having two major national varieties such as British and American (Pyles and Algeo,1993). British English (BrE), usually the 'standard form' refers to the Queen's English, the BBC English, the Oxford English and the Received Pronunciation (RP) etc. On the other hand, American English (AmE) which is the language of the U.S.A. or North American people, the US media (e.g. the US radio, the US TV etc) and some of its dialects is commonly termed as General American English (GAm/GA). American English has lately got more influence in the world affairs as a result of the fall of the then USSR, an impact of globalization, open market economy, American popular media, culture and the internet etc but the number of BrE users is still greater than that of AmE. Today, the misuse as well as the misconception in handling these two varieties of English is noticed which should be possibly avoided. It is noted there are few differences in grammar of $\mathrm{BrE}$ and AmE (Swan, 2005). So, in the study of BrE and AmE, pronunciation and vocabulary receive more attention than grammar. Furthermore, there are explanations that grammatical differences are few and the most conspicuous and widely known to speakers of both national standards (Quirk et al, 1972). But most observers of the English language recognize the differences between $\mathrm{BrE}$ and $\mathrm{AmE}$ in the fields of pronunciation, vocabulary and spelling but grammatical differences are more extensive and important than most observers initially recognize (Modiano, 1996). Yet again, despite many differences in detailed features in the use of daily British and American grammars, they are in most of the aspects similar to each other. Some structures might be accepted in one variety of English while it is considered to be ungrammatical in the other although such grammatical differences rarely impede communication (Modiano, 1996). Since a comprehensive study or survey has not yet been done, we can distinguish the BrE and AmE grammars from a few points of view which are not so distinctive but redundant in most cases. Some of the significant differences in grammar, syntax and a few grammar related issues of British and American English are discussed here in this paper.

\section{RESEARCH FINDINGS}

Although English belongs to Indo-European language family and originates from England, it can be categorized into a number of varieties due to the influence of culture of diverse countries, regions etc. Even, it can also vary dramatically within countries, two of it - BrE and AmE - are the well-liked and widely used by 
the people of the world. The other varieties of English are such as Australian English, Canadian English, Indian English, Singapore English, New Zealand English, Welsh English, Irish English (Hiberno-English), Scottish English, Cockney, South African English, Hong Kong English, a newly come out accent termed Estuary English and so forth. So, there exist two national standards significantly predominant both in number of distinctive usage and in the degree to which these distinctions are institutionalized-BrE and AmE (Quirk and Greenbaum, 2013). Observation and study show that British and American English are the two most important, different but related, variants of English with a few distinctive features and many agree that there remain relatively minor discrepancies between the two. The variation in grammars of the two varieties is fewer and most noticeable which are usually identified. These differences in two grammars, in most cases, are a bit superfluous. For example, 'a storm in a teapot' $(\mathrm{BrE})$ has the AmE equivalent as 'a tempest in a teapot' with a synonym of the word 'storm'. Besides, 'I have no time.' (BrE) has its equivalent in AmE as 'I don't have any time'. But now both are used frequently in the grammar of BrE. However, we may find some fully acceptable constructions in one variety which is regarded as ungrammatical in the other. However, in most of the time, yet the use of distinct British English or American English grammar will not impede communication. Nonetheless, it will serve the student well to become aware of some of the more apparent dissimilarities (Modiano, 1996). However, the differences in grammar and syntax between British and American English are small but notable. The differences are mainly shown in the usage of nouns, pronouns, verbs, tenses, prepositions, auxiliaries, articles, adjectives, adverbs, subjunctive moods, idioms, punctuation etc.

Nouns: British and American English have a lot of dissimilarities in subjectverb concord (Modiano, 1996). With a singular collective noun, BrE can prefer using either a singular or plural verb whereas a singular verb is used in AmE (Quirk et al, 1985). So, in British English, collective nouns (i.e. nouns referring to particular groups of people or things- government, team, people, class etc) can be followed by both a singular or plural verb depending on whether the group is thought of as one idea or as many individuals. e.g.

My team is winning. Vs. His team are all sitting down.

While in American English, collective nouns are always followed by a singular verb, so an American would usually say:

Which team is losing? NOT *Which team are losing?

But in British English, both plural and singular forms of the verb are possible. e.g. Which team is/are losing?

Genitives: For the genitive/possessive, the general rule for using the $s$-genitive in both British and American English is that animate nouns, particularly in the singular, are constructed with the $s$-genitive, as in the girl's parents, whereas other nouns are constructed with the of-structure, as in the color of my car (Tottie, 2002). 
However, in recent years there has been a noticeable change in the use of $s$-genitive in AmE. The development has shown that abstract nouns, such as swimming and jumping, get the $s$-genitive as well as in the following examples of an English newspaper:

AmE-Anita Nall and Summer Sanders-swimming's "New Kids on the Block" AmE-[S]how jumping's prize money doesn't yet approach golf or tennis . . .

(Hundt, 1997)

Articles: There is a remarkable difference in the use of articles in $\mathrm{BrE}$ and AmE. For example, BrE has both the use of 'a' and 'an' depending on vowel and consonant sounds but AmE prefers ' $a$ ' even with words beginning with vowel sounds in informal use such as $a$ orange. Whereas AmE has a striking use of definite articles with some words such as hospital, university etc. e.g.

BrE- He is in hospital. (BrE- a patient)

AmE-He is in the hospital. (BrE- other than a patient)

BrE- He is at university.

AmE-He is at the university.

(Tottie, 2002)

The examples of phrases which require no definite article in British English; members of staff (BrE) but in American English, they are used with a definite article; members of the staff $(\mathrm{AmE})$, for indefinite article; on average $(\mathrm{BrE})$, on the average (AmE). There are constructions in which BrE has a definite article, as in in the light of these developments, while AmE does not, as in in light of these developments, though both constructions are accepted in AmE (Modiano, 1996).

Pronouns: Differences in pronouns are a few between British and American English. In BrE, the indefinite pronoun one is repeated in co-reference where AmE uses he (Quirk et al, 1972). An Englishman will say, "If one loses one's temper, one should apologize." while an American will say, "If one loses his temper, he should apologize." Thus, Englishman will use the pronoun 'one' for all the times but an American will use the third person pronoun (i.e. s/he) for 'one'. Moreover, the Americans prefer to use the relative pronoun 'who' rather than 'whom'. e.g.

BrE- Whom do you want to see?

AmE-Who do you want to see?

Verbs: In AmE, the modal auxiliary verbs like 'shall', 'should' etc could be used with all persons but they are very rare and unusual where 'will' and 'would' are normal in use. In BrE, 'shall' is restricted only to first persons and is used frequently. Likewise, 'should' is less used in AmE than in BrE. In BrE, 'shall' is used in formal invitation. e.g.

Shall we dance? 
Let us compare some other examples:

BrE- I shall go. (will- used mainly in spoken English)

AmE-I will go. (will- both in written \& spoken English)

British English tends to use the construction with should where AmE generally uses the present subjunctive. The modals such as 'will' and 'would' in British English is often used in predictive sense whereas in American English 'should' or 'must' is used for the same. e.g.

BrE- Would we always tell you?

AmE-Should we always tell you?

BrE- You oughtn't to have done.

AmE-You shouldn't have done.

In $\mathrm{BrE}$, the verb frequently functions as what is technically referred to as a 'delexical' verb, i.e. it is used in contexts where it has a very little meaning in itself but it occurs with an object noun which describes an action. e.g.

I'd like to have a bath.

The verb 'have' is recurrently used in BrE with nouns referring to common activities such as 'washing' or 'resting' rather than in AmE. e.g.

She's having a little nap.

Moreover, the British English structure be + 'going to' is used in informal spoken style whereas American English uses the contracted form as 'gonna' (/gnnə/) to show the future. Nowadays, this American informal shortened word is becoming more popular with many English speakers of other varieties. e.g.

BrE- Are you going to play with them?

AmE- Are you gonna play with them?

It is noticeable that in AmE, the past participle form of 'get' is 'gotten' ('got' is also used to mean 'own', 'possess', 'dominate' etc: He's got a new car.). In BrE, 'got' is much used. e.g.

BrE- He's got a bad cold.

AmE-He's gotten a bad cold.

Past and Past Participle Forms of Verbs: Differences in verb forms are acknowledged as perhaps the most significant dissimilarity between British and American English. A number of BrE verbs have a $t$-inflection while AmE verbs tend to conform to the standardized $-e d$ structure. These differences constitute a subtle distinction in pronunciation which often goes unnoticed (in pronunciation), but indicates in which English a text is written. It is worth mentioning that many 
AmE conjugations are considered standard in BrE, thus both versions are accepted as correct (Modiano, 1996). Again, there are differences in verb morphology between BrE and AmE. With regular verbs the dental suffix is normally realized as [t] after a voiceless consonant, as in stopped, as [d] after a voiced consonant, as in mailed, and as [Id] after a dental consonant, as in wanted. There are features of both endings similarly in BrE and AmE (Tottie, 2002). Though the irregular past forms such as dreamt, spelt etc are possible in American English, they are less common than the forms ending in $-e d$. Here is a diagram for verbs showing different simple past and past participle forms in British and American English.

\begin{tabular}{|c|c|c|c|}
\hline & Infinitive & Simple past & Past participle \\
\hline $\begin{array}{l}\text { BrE } \\
\text { AmE }\end{array}$ & burn & $\begin{array}{l}\text { burnt/burned } \\
\text { burned/burnt }\end{array}$ & $\begin{array}{l}\text { burnt/burned } \\
\text { burned/burnt }\end{array}$ \\
\hline $\begin{array}{l}\text { BrE } \\
\text { AmE }\end{array}$ & bust & $\begin{array}{l}\text { bust } \\
\text { busted }\end{array}$ & $\begin{array}{l}\text { bust } \\
\text { busted }\end{array}$ \\
\hline $\begin{array}{l}\text { BrE } \\
\text { AmE }\end{array}$ & dive & $\begin{array}{l}\text { dived } \\
\text { dove/dived }\end{array}$ & $\begin{array}{l}\text { dived } \\
\text { dived }\end{array}$ \\
\hline $\begin{array}{l}\text { BrE } \\
\text { AmE }\end{array}$ & dream & $\begin{array}{l}\text { dreamt/dreamed } \\
\text { dreamed/dreamt }\end{array}$ & $\begin{array}{l}\text { dreamt/dreamed } \\
\text { dreamed/dreamt }\end{array}$ \\
\hline $\begin{array}{l}\text { BrE } \\
\text { AmE }\end{array}$ & get & $\begin{array}{l}\text { got } \\
\text { got }\end{array}$ & $\begin{array}{l}\text { got } \\
\text { gotten }\end{array}$ \\
\hline $\begin{array}{l}\text { BrE } \\
\text { AmE }\end{array}$ & learn & $\begin{array}{l}\text { learnt/leaned } \\
\text { leaned/learnt }\end{array}$ & $\begin{array}{l}\text { learnt/leaned } \\
\text { leaned }\end{array}$ \\
\hline $\begin{array}{l}\text { BrE } \\
\text { AmE }\end{array}$ & lean & $\begin{array}{l}\text { leant/leaned } \\
\text { leaned }\end{array}$ & $\begin{array}{l}\text { leant/leaned } \\
\text { leaned }\end{array}$ \\
\hline $\begin{array}{l}\text { BrE } \\
\text { AmE }\end{array}$ & plead & $\begin{array}{l}\text { pleaded } \\
\text { pleaded/pled }\end{array}$ & $\begin{array}{l}\text { pleaded } \\
\text { pleaded/pled }\end{array}$ \\
\hline $\begin{array}{l}\text { BrE } \\
\text { AmE }\end{array}$ & prove & $\begin{array}{l}\text { proved } \\
\text { proved }\end{array}$ & $\begin{array}{l}\text { proved } \\
\text { proven/proved }\end{array}$ \\
\hline $\begin{array}{l}\text { BrE } \\
\text { AmE } \\
\end{array}$ & saw & $\begin{array}{l}\text { sawed } \\
\text { sawed }\end{array}$ & $\begin{array}{l}\text { sawed } \\
\text { sawn/sawed }\end{array}$ \\
\hline $\begin{array}{l}\text { BrE } \\
\text { AmE } \\
\end{array}$ & smell & $\begin{array}{l}\text { smelt/smelled } \\
\text { smelled }\end{array}$ & $\begin{array}{l}\text { smelt/smelled } \\
\text { smelled }\end{array}$ \\
\hline
\end{tabular}

206 JELTL (Journal of English Language Teaching and Linguistics), Vol. 2 (3), 2017 


\begin{tabular}{|l|l|l|l|}
\hline BrE & spoil & spoilt/spoiled & spoilt/spoiled \\
AmE & spoilt/spoiled & spoilt/spoiled \\
\hline BrE & stank & stank & stank \\
AmE & & stunk & stank \\
\hline BrE & wake & woke & woken \\
AmE & & woke/waked & woken \\
\hline
\end{tabular}

Tenses: The users of British English generally employ the present perfect tense far more than those of American English users. In spoken American English, it is very common to use the simple past tense as an alternative to situations where the present perfect would usually have been used in British English. e.g.

(a) Sentences which talk about an action in the past having an effect in the present:

BrE- Najin feels ill. He's worked a lot.

AmE-Najin feels ill. He worked a lot.

Or, Najin feels ill. He has worked a lot.

(b) In sentences which contain 'just' are used with perfective and progressive tenses in BrE while past simple in AmE. e.g.

BrE- He has just finished the lunch.

AmE-He just finished the lunch.

Or, He has just finished the lunch.

(c) In sentences which contain the words 'already', 'yet', 'never' or 'ever': yet and already are usually used with perfective and progressive tenses in $\mathrm{BrE}$ while yet is used with past simple in AmE. e.g.

BrE- We haven't told them about the incident yet.

AmE-We didn't tell them about the incident yet.

In American English, the past simple is often used to give new information or to announce a recent happening. e.g.

I lost my pen.

Can you help me with that of you?

Adverbs: There are a small number of differences in adverbs between British and American grammar. e.g.

BrE- I'll be with you presently. (soon)

AmE-I am presently living in Dhaka. (now) 
BrE- The car looks a nice one.

AmE-The car looks like a nice one.

Prepositions: There are divergences and changes in the use of prepositions in British and American English (Modiano, 1996; Tottie, 2002). In fact, the use of prepositions both in $\mathrm{BrE}$ and $\mathrm{AmE}$ is very peculiar and complex. For instance, in British English, when 'home' is used as an adverb, the preposition 'at' is required before 'home' but, in American English, 'at' is not needed. In British English, before 'day', 'week' or 'certain day', preposition 'on' shall be used, while it is not so in American English. e.g.

BrE- I'll see you on Monday.

AmE-I'll see you Monday. (without any prepositions)

The following differences in British and American English are often noticed in the use of prepositions (Tottie, 2002). e.g.

BrE- He walked towards the post office.

AmE-He walked toward the post office.

BrE- He found it among the flowers. (also AmE)

AmE-He found it amongst the flowers.

The table below shows the differences of $\mathrm{BrE}$ and AmE usage of prepositions (Norbert Schmitt, 2006).

\begin{tabular}{|l|l|}
\hline \multicolumn{1}{|c|}{ British English } & \multicolumn{1}{c|}{ American English } \\
\hline live in main street & live on main street \\
\hline fill in a form & fill out a form \\
\hline at the weekend & on the weekend \\
\hline check up on something & check out something \\
\hline $\begin{array}{l}\text { Britons are in two minds about } \\
\text { something. }\end{array}$ & $\begin{array}{l}\text { Americans are of two minds about } \\
\text { something. }\end{array}$ \\
\hline Britons can cater for all tastes. & Americans can cater to all tastes. \\
\hline ten minutes past seven & ten minutes past/after seven \\
\hline five minutes to seven & five minutes to/of seven \\
\hline Friday to Sunday & Friday through Sunday \\
\hline different from/to & different from/than \\
\hline
\end{tabular}


We could have a look at some more differences in the examples below:

BrE- $\mathrm{He}$ is in the team.

AmE-He is on the team.

BrE- It is ten to six. (5:50)

AmE-It is ten of six. (5:50)

BrE- This laptop is in a sale.

AmE-This laptop is on sale.

BrE- Look out of the window.

AmE-Look out the window.

BrE- I haven't seen her for ages.

AmE-I haven't seen her in ages.

BrE- I'm visiting her tomorrow.

AmE-I'm visiting with her tomorrow.

BrE- He wrote to me.

AmE-He wrote me.

BrE- The park is open daily May to July inclusive.

AmE-The park is open daily (from) May through July.

Conjunctions: Sometimes, the Americans drop the conjunctions while the British retain them. e.g.

BrE- Come and take a look.

AmE-Come take a look.

Tag-questions: The positive-positive form of Tag-questions is preferable in BrE to AmE. e.g. They are here, are they?

Whereas the Negative-negative form of Tag-questions is found only in British English. e.g. They did not do it, didn't they?

Punctuations: BrE uses double inverted commas for quotations while AmE uses single. e.g.

BrE- Kamal said, "She went to the park".

AmE-Kamal said, 'She went to the park'.

The comma is used differently in BrE and AmE. For example, when listings occur in writing (e.g. 3 items), there is no comma between the second and the last item in BrE, while there is a comma following the second to the last item in AmE:

BrE- The cover has red, white and blue flowers.

AmE-The cover has red, white, and blue flowers. 
In $\mathrm{BrE}$, it is required to place a full stop for abbreviations and acronyms (hardly any). Whereas in AmE, one is free to leave those full stops out most of the time. So, for example, in BrE one may see these abbreviations being used: Dr., Mr., Mrs., Ms., St., U.N., A.M., P.M. etc where AmE users will see the same list more like this: Dr, Mr, Mrs, Ms, St, UN, AM, PM etc.

In British English, hyphens are frequently used to connect prefixes with the main word. e.g. post-war, co-operation. But they are less common in American English. e.g. postwar, cooperation etc.

Idioms: A number of English idioms that have essentially the same meaning show lexical/syntactic differences between the British and the American variety. e.g.

BrE- touch wood

AmE-knock on wood

BrE- do a deal

AmE-make a deal

BrE- on average

AmE-on the average

BrE- a new lease of life

AmE-a new lease on life

BrE- a home from home

AmE-a home away from home

BrE- touch something with a bargepole

AmE-touch something with a ten-foot pole

BrE- flogging a dead horse

AmE-beating a dead horse

BrE- behind the building

AmE-in back of the building

BrE- half an hour

AmE-a half hour

BrE- in future (any time in future/from now on)

AmE-in the future (BrE- definite time/at some future time)

BrE- a drop in the ocean

AmE-a drop in the bucket, a spit in the ocean

BrE- leave on Monday

AmE-leave Monday

BrE- The River Thames

AmE-The Hudson River 
BrE- a storm in a teapot

AmE-a tempest in a teapot

Writing Dates: Dates are usually written differently in the short (numerical) forms in BrE and AmE. The difference in short-form date order can lead to misunderstanding for anyone, of course, who is not using that variety. For example, 06/04/17 could mean either 6 April 2017 (if seen as in UK format) or June 4, 2017 (if read as US format). e.g.

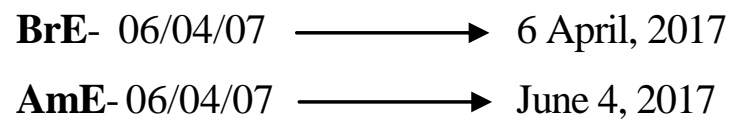

In British English, the standard way of writing dates is to put the day of the month as a figure, then the month (either as a figure or spelt out) and at last the year. For example, 19 September, 2017 or 19.09.17. The standard way of writing dates in American English is to put the month first (either as a figure or spelt out), then the day of the month, and the year at the end. For example, September $19^{\text {th }} 2017$ or 9/19/17. Commas are also frequently inserted after the day of the month in the USA. For example, September 19, 2017 etc. The ISO format is shown as: year, month and then day. e.g. 2017.09.19 etc.

Let's examine some more miscellaneous differences to understand better:

BrE- I have got a new computer.

AmE-I have a new computer.

BrE- He suggested me to buy a piece of land.

AmE-He suggested that I buy a piece of land.

BrE- They needn't come to school today.

AmE-They don't need to come to school today.

BrE- I have no time. (also AmE)

AmE-I don't have any time. (only AmE)

BrE- He is rich enough to try. (also AmE)

AmE-He is rich enough that he can try.

BrE- He has got a temperature.

AmE-He has a fever.

BrE- I've just had some bad news.

AmE-I just got some bad news.

BrE- These shoes are a bit tight.

AmE-These shoes are a little bit tight.

BrE- He lives in the ground floor.

AmE-He lives in the first floor. 
BrE- Have you phoned her yet? (also AmE)

AmE-Did you call her yet?

BrE- That's real fun!

AmE-That's real funny! (informal)

BrE- She read/studied biology at Cambridge.

AmE-She majored/studied in biology at Harvard.

BrE- I wish I had done it.

AmE-I wish I would have done it.

BrE- See the wood for the trees.

AmE-See the forest for the trees.

BrE- Take it with a pinch of salt.

AmE-Take it with a grain of salt.

\section{DISCUSSION}

Grammar, in general, is defined as the whole system and structure of language usually taken as consisting of syntax, morphology and so on. It governs or controls the syntactic but not the semantic construction of language and for one semantic expression there may be different grammars. Grammar is always changing, and many new ways of using grammar in BrE have come from AmE because of many reasons and motives such as the influence of American popular culture and media, globalization and the internet etc. There are fewer grammatical differences in writing than in speaking in the two varieties of English. So, the grammar of the two types has some changes but they are not a huge.

It was the British people who introduced the English language to America in 1607 by British colonization, but the language has evolved into its own version in the USA. The language also extended over many other parts of the world because of British trade and colonization elsewhere and the spread of the former British Empire. By the year 1921, it influenced over a population of 470 to 570 million people which were one-fourth of world population approximately. Now, American English is not a separate language but a distinct kind of English and it is not only a variety of English but also an independent language. Many old usages of English of $17^{\text {th }}$ century have been survived in standard American English. With the rapid advancement of science and technology, trade and commerce and the fall of the then USSR, the USA has become the most powerful nation and a monopolistic power in the world's affair at the end of $20^{\text {th }}$ century and so American grammar for English has spread everywhere very quickly. Now many individuals are far and wide eager to learn American English because of its grammar being easy and simplified.

Although it would a biased job to talk about the advantages and the disadvantages of the two varieties of English, some fact will be apparent to the users of the language if we put forward some arguments. A study carried out in 2010 by the Department of English Languages and Literatures at Gothenburg University on some Swedish school teachers aged 23 - 42 years suggested that BrE is considered, among other things, "nice", "formal", "correct", while AmE is 
described as being "friendlier", "young approached" and "down to earth", with those preferring the former were in the older age group and those preferring the latter were in the younger age group.

\section{CONCLUSION}

Today we live in a global village where all its inhabitants are badly in need of a common and convenient language to communicate. In this regard, the consideration for English comes first as it is a most common and widely used language followed by French on earth. It is spoken all over the world. However, it has so many varieties of which two national variants are the major ones- British and American English. Besides, English is a dynamic and fast developing language and so the changes of its varieties are to be welcomed under some international authority. We know international language refers to a language, as a foreign or second language, that is used for general communication among the nations of the world. The English language, usually in its 'standard form 'either when used, taught or studied as a lingua franca for the whole world is termed the international language. So, we hope the interchangeabilites and the borderline differences of the two varieties will be optimum very soon. The main differences between British English and American English are in pronunciation, spelling and lexicon. So, grammar and syntax have comparatively less change.

Assessing the above differences with care, we can very clearly say that the amount of differences of grammar between the two varieties - BrE and AmE - is not a huge. We can also find the fact that the mixing up of the two varieties does not exactly pose a great deal of severe problems all the time. So, if this process of sharing and borrowing goes on, the learners and/users of the English language will greatly be benefited and the differences of the two varieties will remain at a negligible level. The American grammar in many of the usages is more flexible than that of British. e.g. He's got a temperature. (BrE) Vs. He has a fever (AmE). It is noted that the teaching English in twentieth century demands an accurate awareness of differences between British an American English, because the influence of both varieties throughout the world (Salama, 1976).

In fine, it is worth remembering that George Bernard Shaw says- England and America are two countries divided by a common language. However, we could hope that from the knowledge of differences of the two varieties of English- BrE and AmE- one will feel comfortable in handling them and soon we will get English in a 'mutual form' accepted by all for the sake of universal human communication.

\section{References}

Algeo, John. (1988). British and American Grammatical Differences- OUP

Baugh, A. C. \& Cable, T. (1978). The History of the English Language- E. Cliffs, Prentice Hall Bailey, R.W. and Görlach, M. (eds.). (1982). English as a World Language. Ann Arbor:

The University of Michigan Press

Crystal, D. (1987). The Cambridge Encyclopedia of Language- CUP

Crystal, D. (1997). English as a Global Language- CUP

Close, R. A. (1975). A Reference Grammar for the Students of English- Longman Group Ltd. 
Garner, Bryan A. (2009b). Garner's modern American usage. New York: OUP

Hartmann, R.R.K. and Stork, F.C. (1972). Dictionary of Language and Linguistics Allied Science Publishers Ltd.- UK

Hargraves, Orin. (2003). Mighty Fine Words and Smashing Expressions.- OUP

Hundt, Marianne. (2001). Grammatical variation in national varieties of English- The corpus Based Approach, In: Revue belge de philologie et d'histoire, tome 79, fasc. 3, 2001 Langues et literatures modernes-Moderne taal- en letterkunde. pp. 737-756; pp. 40, doi: 10.3406/rbph.2001. 4545

Johansson, S. (1989). American and British English Grammar - English Studies

Longman Dictionary of Contemporary English. (1987). Longman Group Ltd.

Leech, G. \& Svartvik, J. (1975). A Communicative Grammar of English- Longman Group Ltd.

Lindell, Christian. (2014). British or American English? - An investigation of awareness of the differences in British and American vocabulary and spelling, PhD Thesis, University of Halmstad

Modiano, Marko. (1996). The Mid-Atlantic Handbook: American and British English. 1st ed. Lund: Student litterateur, pp. 125, 126

McAurther, Tom. (1992). The Oxford Companion to the English Language- OUP

McAurther, Tom. (2002). The Oxford Guide to World English.- OUP

Murphy, R. (1985). Intermediate English Grammar- CUP

NCTB. (2001). English For Today (Classes: XI - XII)- Dhaka, Bangladesh

Oxford Advanced Learners' Dictionary of Current English, (2000)- OUP

Peters, Pam. (2004). The Cambridge Guide to English Usage. Cambridge-CUP

Pyles, Thomas and Algeo, John. (1993). The Origins and Development of the English Language, $4^{\text {th }}$ ed. Harcourt Brace Jovanovich, pp. 212

Quirk, R. et al (1972). A Grammar of Contemporary English, Longman Group Ltd, Essex CM20 2JE, England, pp. 20

Quirk, R. et al (1985). A Comprehensive Grammar of the English LanguageLongman Group Ltd, New York, USA, pp. 19

Quirk, R. and Greenbaum, S. (2013). A University Grammar of English, Abridged Edition, Longman Group Ltd, New York, USA

Salama, Nancy.(1976). Teaching Foreign Language Skill. Chicago: The University of Chicago Press.

Schmitt, N. and Marsden, R. (2006). Why is English Like That? Historical Answers to Hard ELT Questions, University of Michigan. Press

Swan, M. (2005). Practical English Usage, $3^{\text {rd }}$ ed.- OUP, pp. 39

Tottie, G. (2002). An Introduction to American English. 1st ed. Malden, Ma: Blackwell Publishers. pp. 148, 172

Trudgill, Peter and Hannah, Jean. (2002). International English: A Guide to the Varieties of Standard English, 4th ed. London: Arnold

Zhang, Bin and Jiang, Zhaofeng. (2008). On Grammatical Differences between Daily British and American English, Asian Social Science, V.- 4, No.- 6, June, pp. 69-73 